\title{
Elektronik Belgelerin Diplomatik Analizi ve Arşivsel Bağın Kurulmasındaki Önemi: Türkiye'deki Uygulamalar Işığında Bir İnceleme
}

\author{
Diplomatic Analysis of Electronic Records and Its Significance \\ in Establishing Archival Bond: A Review in the Light of \\ Applications in Turkey
}

Niyazi ÇIÇEK*

\begin{abstract}
Öz
Türkiye'de elektronik belge kullanımı, Elektronik Imza Kanunu'nun çıkmasının ardından daha da yaygınlaşmıştır. Ancak, bu olumlu gelişme bazı problemleri de beraberinde getirmiştir. Son dönemde bu belgelerin uzun süreli saklanmaları durumunda özgünlüklerini muhafaza edemeyecekleri sorunu tartışılmaktadır. Bu sorunun sebebi elektronik belgelerin iletilmeleri sırasında bazı form özelliklerinin kaybolması, belgenin ait olduğu dosya ve diğer belgelerle ilişkisinin kopması gibi ihtimallerdir. Bu sorunlardan biri de "elektronik belgelerin arşivsel bağının kurulamaması" meselesidir. Arşivsel bağ, bir belgenin form özelliklerini kullanarak üreticisi ve aynı fonksiyon kapsamındaki diğer belgelerle olan ilişkisini tespit edebilmektir. Bu bağın ortaya çıkarılmasında kullanılan önemli bir araç diplomatik metottur. Elektronik belgenin arşivsel bağı, onun üretildiği yazılım, zaman damgası, elektronik imza sahibi, imza güvenliğini sağlayan elektronik sertifika hizmet sağlayıcısı ve üstveri elemanları gibi birçok etken göz önünde bulundurularak analiz edilir. Bu araştırmada, diplomatik metodun elektronik belgelerin özgünlüğünü tespit için kullanılacak arşivsel bağa katkısı incelenmiştir.
\end{abstract}

Anahtar sözcükler: Belge tipolojisi, Elektronik belgelerin diplomatiği, Arşivsel bağ, Belge yönetimi

\section{Abstract}

The widespread use of electronic records in Turkey is achieved only after the promulgation of a new law regarding to electronic signature. However, this positive development has also brought certain problems. It is debated whether or not these records can maintain their authenticity if they are to be preserved for extended periods. This problem is closely related with the possibility that, in case that they are delivered in an electronic environment some form features can be lost, the electronic signature might become invalid, and the record can be detached from the file it actually belongs to. One of these problems lies in theflack of electronic records' archival bond. Archival bond

* Doç. Dr.; İstanbul Üniversitesi Edebiyat Fakültesi Bilgi ve Belge Yönetimi Bölümü, İstanbul. (bilgibelgeci@hotmail.com) 
implies the determination of the nature of relationship between the creator of a record and other records that have more or less the same function. Diplomatic method is regarded as a significant means of specifying this bond. In examining the archival bond of electronic records, several factors are to be taken into consideration, including its software within which it was initiated, its time stamp, the owner of electronic signature, electronic certification service to secure the signature and also metadata elements. This study seeks to indicate the contribution of diplomatic method to archival bond to be used for the evaluation of the authenticity of electronic records.

Keywords: Records typology, Electronic records diplomatics, Archival bond, Records management

\section{Giriş}

Kağıt belgeler yanı sıra elektronik belgelerin üretilip kullanılması da belge yönetimindeki iş sürecinin önemli bir adımını oluşturur. Bu belgeler, yazışma kuralları ve ait oldukları faaliyetin ne şekilde yürütüleceğini gösteren yönetmelik, yönerge, esas şeklinde bir takım prosedürler çerçevesinde düzenlenirken, sahipliği ile alâkalı olarak elektronik imza biçiminde araçlar devreye girer. Her ne kadar Elektronik İmza Kanunu (2004) gibi hukuki düzenlemelerin ardından elektronik belgelerin kullanımı daha güvenli hale gelse de yönetilmeleri sırasında, uzun sure koruyamamak, emanet zincirini tam kurumamak, dosya ve belge bütünlüğünü sağlayamamak gibi çeşitli sorunlar, hâlâ tam çözüme kavuşturulamamıştır. Bu konuda Türkiye'de bir takım çalışmalar (Beder, 2005; Kandur, 2006; Elektronik, 2009) yapılmış olsa da uygulama sırasındaki somut olumlu sonuçları görmek, henüz erken gözükmektedir.

Bu sorunların başında, elektronik belgelerin özgünlüğünün korunamaması meselesi gelmektedir. Özgünlük sorunu aynı zamanda güvenilirliği gündeme getirmektedir. Her ne kadar bilgisayar teknolojisine dayalı çeşitli bilgi güvenliği programları bulunsa da uzun süreli muhafazalarda bu güvenlik sorununun arşivcilik bakış açısı ile de ele alınması gerektiği anlaşılmaktadır.

Çalışmanın konusu belirlenirken, belirtilen olumsuzlukları gidermenin bir yolunun, elektronik belgelerin diplomatik analizi yapılarak kurulacak arşivsel bağ olabileceği anafikrinden yola çıkılmıştır. Bu araştırma, gerekli teknik donanıma sahip olarak yapılacak diplomatik kritik ile kurulacak arşivsel bağ sayesinde elektronik belgelerin güvenilirliğinin sağlanabileceği temasına dayanmaktadır. Bu düşünce, bir yönüyle belgelerin üretilmesi, kullanılması, dosyalanması, transferi ve arşivlenmesi safhalarındaki emanet zincirini ortaya çıkarmaktır. Araştırmanın konusu, bu zincirin kurulmasında arşivsel bağın rolü ile sınırlandırılmıştır.

Problemlerin bir kısmı bugün tartışılırken, iletişim teknolojisi alanında yaşanan hızlı gelişmelere bağlı olarak gelecek on yıl ve daha sonrası için arşivcileri ve belge yöneticilerini ne tür sorunların beklediğini bilmek şimdilik mümkün gözükmemektedir. Ancak gerçek olan, bu teknolojik gelişmeler karşısında bilgi ve belge uzmanlarının 
kendilerini yenileyerek elektronik bilgi taşıyıcı ortamlar için geleneksel uygulamalar yanı sıra yeni müdahale teknikleri geliştirmeleri gerektiğidir. Diplomatik açıdan elektronik belgeleri inceleme yöntemi, her ne kadar on yıl önce tartışılmaya başlanmış olsa da uygulama tekniği bakımından hâlâ güncelliğini korumaktadır. Burada ortaya konulmaya çalışılan yazılım ve donam ile ilgili olarak bilgi teknolojisindeki son gelişmeler ve yaşanan tartışmalar değil, elektronik belgelerin özgünlüğünün korunmasında kullanılabilecek bir yöntemi açıklamaktır. Genelde bilgi teknolojisi, özelde de elektronik belge yönetimi konusunda gerek akademik çalışmalar, gerekse standart ve mevzuat gibi prosedürlerle alakalı gelişmeleri değerlendirmek, takdir edileceği gibi bu makalenin hacmini aşan bir durumdur. Burada amaçlanan farklı ülkelerde denenmeye çalışılan belge inceleme yöntemlerinin Türkiye'de uygulanabilirliğine katkı sağlayıp, bu gelişmelere arşivcilerin dikkatini çekmektir. Bu yapılmaya çalışılırken elektronik belgelerin diplomatik özellikleri ile ilgili genellikle farklı ülkelerde yayınlanmış yabancı dilde eserler değerlendirilirken, elektronik belge üretimi ve yönetimi konusunda ise son dönemde Türkiye'de yapılan çalışmalar ağırıkklı olarak kullanılmıştır.

Elektronik belge, farklı amaçlar için her sektörde üretilip kulanılmaktadır. Bu yazı kapsamında ele alınıp değerlendirilen elektronik belgeler, daha çok kamu kurumlarında kullanılanlardır. Dolayısıyla araştırmada belge olarak ifade edilen materyale ilişkin örnekler, kamu idaresine ait iş ve işlemlerde en fazla tercih edilen yazılı iletişim formu olması nedeniyle resmi yazışmalardan oluşmaktadır.

\section{Elektronik Belge}

Belge, kâğıt ortamda üretilebildiği gibi elektronik olarak da düzenlenebilir. Elektronik belgelerin en önemli özelliği taşıyıcı ortamın anolog bir sistemin değil, iletişim teknolojilerinin bir ürünü olmasıdır. Buna bağlı olarak elektronik belge, bir elektronik araç vasıtasıyla sayısal ortamda üretilen, gönderilip alınabilen ve depolanan kayıt olarak değerlendirilebilir (Electronic, 2007, s. 3).

Kâğıt ortamdaki bir belgenin hukuki bakımdan geçerliliği konusunda aranan, "anlaşılır sembollerle üretilmiş olmak", "taşınabilir olmak", "bir iradeyi açıkça ifade etmek" ve "düzenleyeni belirleyebilmek" yani belgenin hukuki sorumluluğunu alan kişinin imzasının bulunması biçiminde birçok özellik, elektronik belgeler için de kabul edilmiştir (Artuk, Gökcen ve Yenidünya, 2006, ss. 407-412). Bunlar arasında ön plana çıkan, belgede kimlik tespitidir. Elektronik belgede kimlik tespiti elektronik imza ile yapılır. Bu yolla belgenin aidiyetinin belirlenmesi, güvenilirliğinin ve özgünlüğünün sağlanması yanı sıra ağlar aracılıyla iletimi, kullanımı ve muhafazası sırasında güvenliğinin temin edilmesi amaçlanmaktadır.

Türkiye'de gerek hukuki prosedürlerde, gerekse standartlarda ve çeşitli kaynaklarda elektronik belgeyi açıklayan tanımlar yapılmıştır. Örneğin Maliye Bakanlığı, yayınlamış olduğu bir tebliğ ile mükelleflerin daha önce kullanmış oldukları belgeleri elektronik olarak da üretebileceklerini belirtmiş, elektronik belgeyi ise şekil hükümleri bakımından 
bağımsız olarak, Vergi Usul Kanunu'na göre düzenlenmesi zorunlu olan belgelerde yer alan bilgileri içeren elektronik kayıtlar bütünü şeklinde tanımlamıştır. (Maliye Bakanlığı, 2006). Tanımda elektronik imza kullanma şartı doğrudan belirtilmemiş, açıklama Elektronik Imza Kanunu gibi prosedürlerden bağımsız düşünülmüştür.

Elektronik belge yönetimi çalışmalarında yapılan elektronik belge tanımlarında ise daha çok arşivcilik, diplomatik ve belge yönetiminin göz önünde bulundurulduğu anlaşılmaktadır. Örneğin elektronik belge yönetimi standardının hem 2007'de yayınlanan ilk baskısında, hem de gözden geçirilerek yenilenen 2009 yılında çıkarılan ikinci verisyonunda elektronik belge, herhangi bir bireysel veya kurumsal fonksiyonun yerine getirilmesi için alınmış ya da fonksiyonun sonucunda üretilmiş, içerik, ilişki ve formatı ile ait olduğu fonksiyon için delil teşkil eden kayıtı bilgi olarak tanımlanmıştır (Türk Standartları Enstitüsü [TSE], 2007, s. 2; TSE, 2009, s. 1).

Kullanıldığı alana göre elektronik belgelerin tanımlanmasında farklılıklar bulunabildiği görülmektedir. Özellikle elektronik belge yönetimi ile ilgili çalışmaların getirdiği açıklamalar dikkat çekicidir. Hukuki ve idari işlemler açısından elektronik belgenin kimlik tespiti ve orijinalliği önemli iken, belge yönetimi çalışmalarında otantiklik yanı sıra belgenin bir fonksiyon neticesinde üretilmesi, içerik, organik ilişki ve format itibariyle üretildiği fonksiyona ait işlemlerin delili olması ön plana çıkmaktadır. Örneğin bir ihale fonksiyonunda ihale komisyonu tutanağı, komisyonunun yürüttüğü işlemi belgelemesinin yanı sıra yürütülen işlemin ve alınan kararın delili olup fonksiyon kapsamında yürütülecek daha sonraki işlemlerin de dayanağıdır.

\section{Diplomatik Açıdan Belge Tipolojisi}

Tipoloji kavramını, genellikle arkeolog ve antropologların, buluntuları aynı zamanda hayvan ve insan tiplerini tasnif edip nitelemek için kullandıkları bilinir. Belgelerin özgünlüğünü sağlayan temel bileşenleri analiz edebilmek için arşivciler ve belge uzmanları (diplomatist) da bu tipoloji yöntemini kullanırlar. Burada uygulanan iki yöntem vardır: Nesneleri genelden özele veya özelden genele doğru sınıflandırıp nitelemek (The International Research on Permanent Authentic Records in Electronic Systems Project [InterPARES Project], 2000b, ss. 4-5). Belge uzmanlarının diplomatik kritik için kullandığı metot ise genelden özele doğru olanıdır.

Belgeleri otantiklik açısından inceleme metodu olan ve asıl belgeleri sahtelerinden ayırmak amacıyla XVII. yüzyılda teorik temelleri atılan diplomatik, belgeleri belirli kategorilere ayırarak analiz eder. Diplomatik uzmanları belgeleri, üretilme gerekçeleri, aynı zamanda form özellikleri itibariyle yüklendikleri hukuki sorumluluğa göre bir takım kategorilere ayırmışlardır. Dolayısıyla içerisinde sadece okunabilen yazılı bilginin yer aldığı dokümanlar yanı sıra taşıması gereken hukuki ve idari form özelliklerine sahip belgeler bulunmaktadır. Diplomatik uzmanları modern belge tipolojisini dört kategoride ele almışlardır: 
$\diamond \quad$ Tasarruf yetkisi veren belgeler

$\diamond$ Kanıtlayıc belgeler

$\diamond$ Destekleyici belgeler

$\diamond$ Açıklayıcı belgeler (Duranti, 1998, ss. 65-66; InterPARES Project, 2000a, s. 7).

Modern belgelerin diplomatiğiyle ilgilenen uzmanlar, daha önce gerçekleşmiş hukukî bir sonucu açıklayan kayıtları tasarruf yetkisi veren belgeler (dispositive records) olarak adlandırmışlardır. Bundan sonra yapılacak hukuki işlemler bu tür belgelerde ortaya konulmuş olan iradeye göre belirlenir. Ruhsatlar, vasiyetler, sözleşmeler ve kontratlar gerçek ve tüzel kişilere yetki veren belge örnekleridir. Eğer belgenin üretilme gerekçesi olmuş bitmiş bir fiilin, yapılan bir uygulamanın, idari bir işlemin delili olmaksa, bu durumda belgenin öncelikle kanıtlayıcı bir yönünün bulunduğu anlaşılır. Bu tür kayıtlara kanıtlayıcı belge (probative records) denilmiştir. Vergi beyannameleri, her çeşit fatura ve makbuzlar, çeşitli ödeme belgeleri ve günlük yazışmalar bu grubun örneklerini oluşturur (Çiçek, 2009, s. 74). Zaten, Vergi Usul Kanunu'nun (1961) 227. Maddesi defter, fatura, makbuz gibi belgeleri "ispat edici belge" olarak tanımlamıştır.

Diplomatik uzmanları bu tasnifi, bir belge türü için değil, tüm dokümanları kapsayacak şekilde yapmışlardır. Belge tipolojisi bakımından bu nitelemenin genelden özele doğru yürütüldüğünü söylemek mümkündür. Dolayısıyla bir diploma, maaş bordrosu, atama kararnamesi, bakanlar kurulu kararı ya da ihale komisyonu kararı, günlük iş planı, ziyaretçi listesi gibi çok çeşitli kayıt türü, üretilme amacı ve yapısal özelliklerine bakılarak ya bir belge ya da doküman olarak bu tasniflerden birinde yer alabilir.

Bu tasnifte göze çarpan en önemli husus, gruplar arasındaki tanımsal farklılıktır. Özellikle ilk iki grup yasal belgeleri (legal records), diğer ikisi ise yasal olmayanları ifade etmektedir (Duranti, 1998, s. 66). Tasniflerde yer alan belge türlerinin niteliklerine bakıldığında, ilk iki grubun hukuki bakımdan bir belgenin taşıması gereken özellikleri barındıran belgeler olduğu görülür. Üçüncü ve dördüncü grupta yer alan destekleyici belgeler (supporting records) ile açıklayıcı belgeler (narrative records) ise kimlik tespitine yarayacak bir işaret ve mühür gibi hukuki zorunlulukları taşımayan; dolayısıyla hukuki bakımdan belge olma özelliklerine sahip olmayan yazı ve dokümanları oluşturur. Burada belgeler ile belge olma özelliği taşımayan kayıtlar ayrılmaktadır. Dolayısıyla belge olarak adlandırılan bir nesne, bir işlemin delili olma, bu hususiyetiyle bir sorumluluğu destekleme, işılemi açıklama, sorumlusunun belli olması gibi niteliklerden dolayı yazı, doküman vb. diğer kayıtlardan ayrılır (Öberg ve Borglund, 2006, s. 57). Bu durumda şunu söylemek mümkündür: İlk iki grup sahip oldukları form özellikleri ile belge (records) olma hususiyetini taşımakta, üçüncü ve dördüncü gruplar ise bilgi amaçlı dokümanları (documents) ifade etmektedir. Belge yönetimi çalışmalarında da hem belge ve doküman hem de belge yönetimi ile doküman yönetimi arasındaki farklar açıkca ortaya konmuştur (Kandur, 2006, s. 13 ; Model Requirements fort he Management of Electronic Records [MoReq], 2008, s. 67; TSE, 2009, s. 1). 
Belge ve doküman tipolojilerini en üst düzeyde bu dört kategoride ele alan diplomatik, daha çok yasal belgelerle ilgilenir. Kâğıt belgeler yanı sıra resim, fotoğraf, mikrofilm gibi taşıyıcı ortamı farklı belgeler için de bu tasnif ve inceleme metodu kullanılabilmektedir (Bartlett, 1996). Dolayısıyla elektronik ortamda üretilen belgeler de bu tasnife tabi tutulabilir.

Üretildiği fonksiyon kapsamında üzerinde yürütülen işlemlere göre her belge türü bir tipolojiye sahiptir. Bu tipoloji, o belgeyi diğer belge türlerinden ayırmaya yaradığı gibi o türün ortak özelliklerinin belirlenmesini sağlar. Belge tipolojisinin incelenmesine imkân verecek yöntemlerden biri de diplomatiktir.

\section{Geleneksel Diplomatikten Çağdaş Arşivsel Diplomatiğe}

Diplomatiğin bugün ulaştığı noktaya gelmeden önceki durumunu ve geçirdiği süreci bilmek, elektronik belgeler üzerine çalışacaklara uygulayacakları yöntem konusunda yol gösterecektir. Diplomatiğin tarihsel süreçdeki gelişimi üç safhada ele alınmaktadır: Bunlar, diplomatiğin kaynağı ve geleneksel yapısı, bu yüzyıla ait modern görünümü ile çağdaş diplomatiktir (MacNeil, 2000; InterPARES Project, 2000a).

Geleneksel diplomatiğin temelleri, 1681'de Fransız Saint-Maur Bénédictin Tarikatı rahiplerinden Dom Jean Mabillion (1632-1707) tarafından Benedictin Azizlerinin hayat hikâyelerini inceleyen De re diplomatica adlı altı bölümlük eseri yayınlamasıyla atılmıştır. Bu eserinde Mabillion, belge inceleme metodu ortaya koymuştur. O dönemde bu metot, devlet yetkililerinin vermiş olduğu resmi belgelerin hukuki ve idari bakımdan otantikliğinin belirlenmesi tekniği olarak kullanılmıştır (Çiçek, 2009, s. 26).

Geleneksel diplomatik anlayışta belgeler çoğunlukla şekil bakımından incelenmiş, belgelerin hukuki ve idari işlemleri ile üretildikleri fonksiyon ikinci planda kalmıştır. Diğer bir ifadeyle, sadece belge formunda görülen parçalar analiz edilmiştir. Bu parçalar, belgenin iç kaynaklı ve dış kaynaklı elemanlarıdır.

Dış kaynaklı elemanlar, o belgenin kâğıt, parşömen vb. taşıyıcı ortamı, bilginin aktarıldığı yazı stili, işaretler, noktalamalar, yazı metninin paragraf biçimindeki şekil düzeni ile belgeyi denetleyenin işareti, doğrulama sembolü, belgenin kaç nüsha olduğu, orijinal veya kopya olup olmadığı gibi bilgilerdir. İç kaynaklı olanlar ise protokol, metin ve son protokol kısımlarıdır. Protokol, belgenin çıktığı kaynağı işaret eden başlık ile başlar ve alıcının adresi gibi bilgilerle devam eder. Metin kısmı, kompozisyon, anlatımın bölümlendirilmesi ile bitiş cümlesinden meydana gelir. Son protokol alanı ise tarih, imza, isim ve varsa mühürden ibarettir (Çiçek, 2009, s. 162).

Geleneksel diplomatik oldukça sade bir belge inceleme metodu ortaya koyarken, XX. yüzyılın özellikle ikinci yarısından itibaren başlayan modern diplomatik çalışmalar, belge analiz yöntemini daha da geliştirmiş, kritik unsurlarına yeni alanlar eklemiştir. 
Modern diplomatiğin yaygınlaştırılmasında rol oynayan başlıca uzmanlardan biri Luciana Duranti'dir. Duranti (1998), kaleme aldığı çeşitli makalelerinde ve diplomatik ile ilgili 1998 yılında yayınladığı eserinde, günümüz belgelerinin diplomatik bakımdan incelenme şeklini daha da geliştirmiş ve analitik bir metot ortaya koymuştur. Duranti ve diğer çağdaş belge uzmanları, şekil ile yetinmemiş, modern bürokrasinin aktörleri olan belgenin üreticisi, sorumlusu, işlem ve hukuk bağlamında yeni bir bakış açısı getirmişlerdir. Belgeyi ortaya çıkaran ve form özelliklerinin biçim almasını sağlayan idari ve hukuki aynı zamanda fonksiyona dayalı etkenleri değerlendirmişlerdir (Storch, 1998, ss. 366-367; Duranti, 1998; Çiçek, 2009).

Belge formunun alanlarını genişleten modern diplomatik, belgenin dış kaynaklı elemanlarını onun fiziksel formu, iç kaynaklı olanları ise entelektüel formu olarak değerlendirmektedir. Örneğin belgenin fiziksel formu alanını niteleyen taşıyıcı ortam ile ilgili olarak materyal, format ve mesajın iletimi için hazırlanması biçiminde yeni alanlar açılarak ayrıntıya inilmektedir. Yazı alanında, belge eğer bilgisayar çıktısı ise bilgisayar yazılımı, yazılımın sürümü, format, yazı karakteri ve font büyüklüğüne bakılır. Belgenin yazıldığı dil kısmında ise kullanılan terminoloji ve yazma stili incelenir. Özel işaretler alanında bürokratik işlemlerden kaynaklanan yazarın özel işaretleri; aynı zamanda memur, şef ve müdür gibi diğer çalışanların belge üzerindeki paraflarına dikkat çekilir. Mühür incelemelerinde mührün kazındığı malzeme, biçimi ve büyüklüğü, baskısı, yazı türü ve varsa sembolleri ele alınır. Belgenin fiziksel formu alanında son olarak notlar ve ilaveler kısmıyla belgede düzeltme ve ekleme notlarına dikkat edilip, belgeye bürolardaki “işlem", "kullanım” ve "yönetim” safhasında yapılan eklentiler incelenir. Evrak kayıt işlemlerinde, belgenin aldığı sayı ve kayıt mührü; kullanım safhasında havale notları ile şerhler; yönetim safhasında ise dosya numarası, arşiv yer numarası, arşivin aidiyet mührü gibi unsurlar analiz edilir (InterPARES Project, 2000a, ss. 9-11).

Belgenin iç kaynaklı elemanlarının "entelektüel form özellikleri" biçiminde tanımlanması, görsellikten daha çok bilgi yönü ağır basan ve okunarak değerlendirilen unsurlar olmaları sebebiyledir. Mesela protokol alanında geleneksel diplomatiğin ortaya koyduğu uygulamalardan farklı olarak belgenin anteti, yanı sıra verilmiş ise belgenin konu başlığı, sayı ve kontrol numarası, aynı zamanda belgenin içeriğini açıklayan anahtar kelimeler değerlendirilir. Metin alanındaki incelemeler, belgede bulunan içeriğin büyüklüğüne göre giriş cümlesi, bildirim, açıklama, değerlendirme, karar gibi kısımlarından oluşur. Son protokol alanında ise geleneksel diplomatik analize ek olarak belgedeki işleme şahit olanlar, ayrıca imzanın dışında belgeyi tasdik eden ve imza yerine kullanılan işaretler incelenir (Çiçek, 2009, ss. 162-163). Görüldüğü gibi entelektüel form elemanları, okunup tahlil edilen, üzerinde akıl yürütmelerinin yapıldığı özelliklerdir.

Modern diplomatiğin ardından, özellikle belgelerin otantikliği konusunda yapılan çalışmalar neticesinde geliştirilen bir anlayış, çağdaş arşivsel diplomatik (Contemporary Archival Diplomatics) de denilen çağdaş diplomatiktir(Duranti ve MacNeil, 1996; 
Delmas, 1996; Williams, 2005). Bu diplomatik anlayışta belgenin güvenliği, güvenilirliği ve otantikliği ile uzun süreli saklanması durumunda arşivsel bağı düşünülmüş, yapılacak belge kritiğinde bu unsurların nitelemesine yarayacak yeni alanlar oluşturulmuştur. Bu diplomatik anlayışın gelişmesinde elektronik belge uygulamalarının etkili olduğu söylenebilir.

Son dönemde, diplomatik gelişmelerin çağdaş arşivsel diplomatikle sınırlı kalmadığı görülmektedir. Bunun en önemli sebebinin, özgünlük konusunun belgenin delil olma yönüyle de ilişkili bulunmasıdır. Özellikle adli alanda kullanılan elektronik belgelerin özgünlükleri ve güvenilirliklerinin sağlanması noktasında sıkı tetbirler alınmaktadır. Arşivciler bu durumda elektronik belgelerin diplomatiğini, adli açıdan da değerlendirip değerlendiremeyeceklerini tartışmaktadırlar (Duranti, 2009). Dolayısıyla elektronik belgelerin diplomatik kritiğini yapabilmek, bilgi ve belge uzmanlarının farklı alanlara açılım yapmalarına da imkan verecektir.

\section{Elektronik Belgelerin Diplomatik Özellikleri}

Yaygınlaşan elektronik belge kullanımı çeşitli problemleri de beraberinde getirmiştir. $\mathrm{Bu}$ problemlerden ön plana çıkan ise elektronik belgelerin özgünlüğünün korunamamasıdır. Bu soruna çözüm üretmek amacıyla diplomatik çalışmaların hızla elektronik ortamda üretilen belgelerin analizini yapmaya yöneldiği görülmektedir. Buna karşılık elektronik belge yönetimiyle ilgili kaynaklarda da belgelerin diplomatik özelliği kavramı, "belgelerin orijinalliğinin tespit edilmesinde kullanılabilecek her türlü içerik, format, ilişki ve sunum özellikleri" biçiminde tanımlanarak kendine yer bulmuştur (TSE, 2009, s. 1). Elektronik belgelerin diplomatik özelliklerini inceleme metodu ile elektronik belgelerin özniteliklerinin tahlili yapılmakta, uzun süreli saklanmaları sürecinde özgünlüklerini koruyup koruyamadıkları ele alınmaktadır.

Son dönemde elektronik belgelerin özgünlüklerinin korunması konusunda makale ve tez olarak yapılan bilimsel çalışmaların yanı sıra ulusal ve uluslararası düzeyde çeşitli projeler yürütülmektedir. Bunlardan biri Kanada'da 1999 yılında başlatılan kısa adı ile "InterPARES" projesidir. Elektronik ortamda üretilen ve kullanılan belgelerin özgünlüğü ve güvenilirliğinin sağlanması, bütünlüğünün korunması ve uzun süre saklanabilmeleriyle ilgili yürütülen uluslararası bir çalışma olan Elektronik Sistemlerde Belgelerin Özgünlüğünün Korunması Üzerine U̧luslararası Araştırma Projesi (The International Research on Permanent Authentic Records in Electronic Systems / InterPARES), elektronik belgelerin özelliklerinin belirlenip otantikliğinin tespitinde yeni yöntemler ortaya koymuştur. Proje, 1999-2001, 2002-2007 ve 2007-2012 dönemleri olmak üzere, üç safhadan meydana gelmektedir (InterPARES, 1999). Kanada takımının koordine ettiği, 2007 yılında üçüncü safhasına başlanan ve 2012 yılında bitirilmesi hedeflenen, 13 ülke tarafından yürütülen projeye, Türkiye on dördüncü ortak olarak 2007 yılında Oslo'da yapılan zirvede dahil olmuştur (Külcü ve Çakmak, 2009). Elektronik belgelerin diplomatik özellikleri bu projeyle ortaya konulan metodoloji ışığında ele alınacaktır. 
InterPARES Projesi çalışmaları neticesinde belirlenen elektronik belge analiz şablonuna göre elektronik belgelerin diplomatik kritiği yapılırken sekiz temel alan üzerinde durulması öngörülmüştür. Bu alanlar, belgenin başlıca iç ve dış kaynaklı form özelliklerini barındıran dokümanter form (documentary form), belge üretildikten sonra onun üzerinde yapılan açıklama notları (annotations), belgedeki iradenin/ mesajın kaydedilip iletildiği taşıyıcı ortam (medium), belge iletilirken aidiyetinin açıklanmasına yarayan kontekst/bağlam (context), fonksiyonel ilişkiyi gösteren arşivsel bağ (archival bond), belgenin üretilmesine sebep olan fiil ve işlemler (action), bunların açıklandığı içerik, (content) ve belgeyi düzenleyen ile katkıda bulunan kişi/ ler (persons) kısımlarından oluşmaktadır (InterPARES Project, 2000a). Bunlar içerisinde daha önceden kâğıt belgeler için yapılan kritiklerde ele alınanlara bu çalışmada çok fazla girilmemiş, özellikle elektronik belgelerin hususiyetlerinden kaynaklanan ve diplomatik incelemelere yeni katılanlar açıklanmıştır. Dolayısıyla çalışma kapsamında değerlendirilecek olanlar beş alan ile sınırlandırılmıştır.

Dokümanter form: Belgenin iç ve dış kaynaklı özelliklerini kapsayan dokümanter form alanı, kâğıt belgeler için kullanılanlarla benzerlik gösterse de elektronik belgenin üretilme koşullarından kaynaklanan bir takım özel niteliklerden dolayı yeni form elemanlarıyla takviye edilmiştir.

Elektronik belgelerin özel bir sunum şekli varsa, bunlar dokümanter form alanının "sunum özellikleri" kısmında belirtilir. Bu sunum şekilleri, özel biçim, zorunlu olarak kullanılan yazı karakteri tipi, aynı şekilde karakterin rengi, metin içerisinde farklı sayfalara bağlantı kurulup kullanıcıyı yönlendiren bağlantılar (hyperlinks), eklentilerin grafik belirtileri, ses dosyalarının örnek oranları (sample rate), görüntü dosyalarının çözünürlüğü, haritaların ölçeği gibi özelliklerdir.

Dokümanter form alanında belge sunumunun bu özel biçimlerinin ardından belgeyi düzenleyen gerçek veya tüzel kişiyi belirlemek için kullanılan "elektronik imza", "zaman damgası" ve "mühür" yer almaktadır. Elektronik imza, yetkili organların belirlediği kriptoloji kurallarına göre oluşturulur. Elektronik ortamda hazırlanan belgenin ait olduğu kişiyi yani hukuki olarak o belgeyi düzenleyeni gösteren elektronik imza, elektronik işlemlerde, WEB ve sanal ortamda kullanılabilen bir imza türüdür. Islak imza ile aynı hukuki geçerliliğe sahip olduğu, 5070 sayılı Elektronik İmza Kanunu (2004) ve ilgili Elektronik İmza Kanununun Uygulanmasına İlişkin Usul ve Esaslar Hakkında Yönetmelik (2005) ile güvence altına alınıp belirlenmiştir. Uygulama alanı oldukça geniş olan elektronik imza, elektronik sözleşmelerde, e-ticaret ile bankacılık işlemleri, kurum içi ve dışı elektronik yazışmalar, sigortacılık işlemleri, e-devlet uygulamaları gibi birçok alanda güvenle kullanılmaktadır.

Elektronik imza, mühür niteliğinde özel işaretler ve zaman damgası, imza güvenliğini sağlayan bir elektronik sertifika hizmet sağlayıcısı aracılığı ile kullanılır. Örneğin Türkiye'de elektronik imza kullanma yetkisi, özel ve kamuya ait kuruluşlarca verilir. Bilgi 
Teknolojileri ve İletişim Kurumundan ([BTK], 2010) daha önce alınan yetkiyle hizmet vermeye başlayan özel firmalar, gerçek kişilere ve özel statüdeki tüzel kuruluşarlara elektronik imza kullanma hizmeti verirken, kamu kurumlarına ise Türkiye Bilimsel ve Teknolojik Araştırma Kurumuna (TÜBITAK) bağlı Ulusal Elektronik ve Kriptoloji Araştırma Enstitüsü (UEKAU) bünyesinde kurulmuş olan Kamu Sertifikayson Merkezi (KSM) tarafından verilmektedir (Kamusm.gov.tr, 2011).

Elektronik doküman formunun önemli özeliklerinden biri "özel işaretler"dir. Örneğin belgenin işleminin tamamlanması için farklı kişilerin onayının alınması veya noter gibi bir tasdik mekanizması gerektiğinde, o kişileri tanımlayan sembollere burada yer verilir. Bu semboller, elektronik filigran (digital watermarks), organizasyon işareti (organization crest), kişisel logo (personal logo) veya kaynak tanımlayıcı (originator identifier) gibi işaretler olabilir (InterPARES Project, 2000c, s. 3).

Elektronik belgenin dokümanter formunun dış kaynaklı elemanları gibi iç kaynaklı olanları da bulunur. Öncelikle kâğıt belgede bulunan antet yani belgenin idari ve hukuki sorumlusu, tarih, belgenin üretildiği yerin ismi, muhatap yani alıcının ismi, belgenin konusu, belgeyi onaylayan (corroboration), tasdik eden ve şahitlik eden (attestation) kişiler, elektronik belgenin de iç kaynaklı elemanlarındandır (InterPARES Project, 2000c, ss. 3-4).

Açıklama notları: Elektronik belgelerin diplomatik hususiyetlerini açıklayan dokümanter formundan sonra ikinci kısmı "açıklama notları" oluşturur. Bu kısım, kâğıt belgeler için kullanılan "ilaveler" alanı ile aynı içeriğe sahiptir. Burada belgenin iletimi sırasındaki muamele, kullanım ve arşivdeki yönetimi sırasında gördüğü işlem ile yapılan eklemeler değerlendirilmektedir.

Taşıyıcı ortam: Belgenin fiziksel taşıyıcısı olan araç bu kısımda tanımlanır. Bu araç, belgenin varlığına veya yokluğuna işaret eder. Örneğin elektronik belge, elektronik ortam olarak kabul edilen fiziksel bir taşıyıcı ile kullanılabilir hale getirilmediği sürece varlığı kabul görmez.

Kontekst: Belgede geçen faaliyetin yer aldığı idari, hukuki ve teknik çatıyı ifade etmektedir. Elektronik ve elektronik olmayan belgelerde beş tür kontekst değerlendirmesi yapılır. Bunlar idari ve hukuki, kaynağa ait, prosedüre ait, dokümanter ve teknolojik kontekstlerdir. Teknolojik kontestin dışındakiler kâğıt belgeler için daha önceden çeşitli kaynaklarda (Duranti, 1998; Çiçek, 2009) ele alındığından bu kısımda sadece teknolojik kontekst değerlendirilecektir.

Teknolojik kontekst alanında donanım (hardware), yazılım (software), veri (data), sistem modelleri (system models) ve sistem idaresi (system administration) kritik edilmektedir.

Elektronik belgelerde donanım için "depo", "mikroişlemci", "bilgisayar ağı" ve "mimarisi" göz önünde bulundurulur. Sistemdeki bilginin tutulduğu yer olan depo (storage), birkaç kısımda ele alınmıştır. Bunların ilki bilgisayar sisteminin ana belleğidir. 
Bu ana bellek (main memory) bilgisayar içerisindeki herhangi bir adrese doğrudan gidip bilgileri okuyabileceği veya yazabileceği anlamında kullanıldığından rastgele erişimli bellek (random access memory) de denilmektedir (InterPARES Project, 2000c, s. 7). İkincisi ana bellekte yapılan işlemler neticesinde elde edilen aynı zamanda dışarıdan transfer edilen verilerin ve dosyaların kaydedildiği asıl depodur (secondary storage). Bilgisayar sabit diski, manyetik veya optik disk, flaş bellek, CD-ROM ve DVD gibi araçlar, bilgilerin kaydedilip tutulduğu depo olarak kullanılır. Diğeri üçüncül depo (tertiary storage) da denilen, daha çok uzun süreli depolama aracı olarak kullanılan manyetik ve dijital teyplerdir. Depo kısmının dördüncüsü, emniyet depoları (storage for security) olarak adlandırılan çoğunlukla veri kurtarma amacı için kullanılan araçların değerlendirildiği alandır. Elektronik belge incelemelerinde donanımla ilgili olarak depo kısmının ardından mikroişlemci (microprocessor) ele alınır (InterPARES Project, 2000c, s. 7). Komutları işleyip, hesaplamaları yaptığı, bilgisayarın içindeki bilgi akışını kontrol edip yönettiği için bilgisayarın temel elemanlarından biri kabul edilir. Elektronik belgelerin diplomatik analizinde donanım kısmının diğer bir ünitesini bilgisayar ağı (network) oluşturur. Sistemler ve bileşenler arasındaki iletişimi sağlayan birincil kaynaktır. Ağ sistemi kendi donanım, yazılım ve mimarisini kapsar. Donanımın diğer unsurları çevresel araçlar (peripheral devices) denilen monitör, yazıcı, klavye vb. parçalardır. Elektronik belgenin üretilip kullanılmasında donanımla alâkalı bileşenler içerisinde hiç şüphesiz bilgisayar mimarisine (architecture) de yer verilmiştir (InterPARES Project, 2000c, s. 9). Mimari ile bilgisayarın merkezi işlem birimi mimarisi, ana kart mimarisi, sistem mimarisi gibi seri ve paralel bağlar, ardışık hatlar biçiminde donanım bileşenleri kastedilmektedir.

Elektronik belgelerin diplomatiği ile ilgili olarak teknolojik kontekstin ikinci ayağında yazılım ele alınmaktadır. Bu kısımda "işletim sistemi", "sistem yazılımı", "ağ yazılımı", "uygulama yazılımı" yer alır.

Yazılım kısmında incelenmesi gereken ilk elemanı, işletim sistemi (operating system) oluşturur. Sistem, elektronik sistemdeki donanım kaynaklarının kullanımını, koruma, kontrol ve yönetim faaliyetlerini yürütür. Başka bir deyişle, donanım ile yazılım arasında köprü vazifesi görür. Bugün Linux, Nowell, Unix, Mac OS, Windows vb. birçok işletim sistemi kullanılmaktadır. Sistem araçları olarak belirtilen sistem yazılımları, işletim sisteminde olduğu gibi uygulama programlarını geliştirmeye, korumaya ve yönetmeye yarar. Makine dilleri, yüksek düzey diller, derleyiciler, yorumlayıcılar ve çeviriciler en belirgin sistem araçlarıdır. Ağ yazılımları (network software), bir veya daha fazla bilgisayar uygulamalarının iletişim gereksinimlerini bir araya getirebilmek için ağları ve onların kaynaklarını yönetir. Protokoller, yönlendirmeler, anahtarlama yazılımları bunun örnekleridir. Elektronik belgenin kritiğiyle ilgili ele alınması gereken bir eleman da uygulama yazılımlarıdır. Bu yazılım (application software), günlük işlemleri yürütmek ve kurumların, bireylerin ihtiyaçlarını karşılamak için geliştirilmiş farklı türlere sahiptir. Tüm dünyada yaygın olarak kullanılan örnekleri, kelime işlemciler, veri tabanı programları vb. yazılımlardır (InterPARES Project, 2000c, ss. 9-10). 
Teknolojik kontekstin üçüncü ayağını veri (data) oluşturmaktadır. Numaralar, karakterler, görüntüler ve elektronik sistem tarafından iletilen, işlenen ve depolanabilen sunum değerleri ile kaydedilebilen unsurlar veri kısmını meydana getirir. Veri kısmında elektronik belgelerin diplomatiği açısından dosya yapısı (file structure) ve veri formatı incelenir. Dosya yapısı, sistem içerisindeki dosyaların organizasyonu ve ilişkileridir. Veri formatı (data format) ise dosya içerisinde verinin organizasyonunu ifade eder. Bunların yapılandııımış ve yapılandııımamış birçok türü bulunur. Microsoft'un ofis programlarından Word2007, ASCII text formatı, PDF (Portable Document Format), zenginleştirilmiş metin formatı RTF (Rich Text Format) tipik veri formatlarından birkaçıdır. Farklı türlerdeki bu veri formatları, hem günlük uygulamalardaki işlem süreçlerinde hem de uzun sureli saklanmaları durumunda ilk üretildikleri gibi korunmalı, erişim ve kullanımlarıyla alakalı da sürdürülebilirlikleri sağlanmalıdır. Bu koruma ve güvenliğin sağlanması konusunda çeşitli standartlar geliştirildiği bilinmektedir (American National Standards Institute-Association for Information Management Professionals [ANSIARMA], 2007). Elektronik belgelerin ve taşıdığı verilerin korunması sürecinde arşivci ve belge yöneticilerine de görevler düşmektedir. Bu tür standartlar, verilerin korunmasıyla ilgili olarak belge yöneticilerine müdahale ve uygulama teknikleri göstermektedir (Kunde, 2009, ss. 147-148).

Sistem modelleri ve sistem idaresi de elektronik belgelerin teknolojik konteksti kısmında ele alınmıştır. Sistem modelleri, farklı sistemler ve programlar arasında fonksiyonel ilişkinin kurulmasını sağlar. Fonksiyonel ilişki, fonksiyonun doğru bir şekilde uygulanıp yürütülebilmesi için iki ya da daha fazla organ arasında gerekli olan iş akışı ilişkisini kurmaktır. Örneğin "adres kayıt sistemi" ile "kent bilgi sistemleri" Birleşik Modelleme Dili (Unified Modeling Language [UML]) diyagramı kullanılarak bütünleştirilmiştir (Tarık, 2008, s. 16). Sistem idaresi, sistemin yürütülmesinde süreklilik olması için güvenilirliği, emniyeti ve doğruluğu sağlayacak prosedürlerin oluşturulmasıdır. Bu prosedürler, dosyaların yedeklerinin alınması, sistemin korunması, depo sistemleri ile donanım ve yazılımın güncellenmesi, yetkili girişlerin belirlenmesi, zaman geçtikçe sistemin yeniliklere entegrasyonu, güvenilirliğin, erişilebilirliğin ve güvenliğin sağlanması gibi hizmetleri kapsar (InterPARES Project, 2000c, s. 11).

Elektronik belgenin diplomatik kritiği yapılırken teknolojik kontekst alanının ön plana çıktığı açıkça görülmektedir. Özellikle uzun süreli muhafazaları ve kullanımlarında belgelerin otantikliği, erişilebilirliği ve güvenliğinin sağlanıp sağlanamaması ile ilgili değerlendirmeler, belirtilen özellikler göz önünde bulunularak yapılır. Burada başlıkları verilen ve kısa açıklamaları yapılan alanlar, diplomatik analiz sırasında sorulara dönüştürülerek kullanılır. Sorularla belge yapısı çözümlendiği gibi elektronik belgenin fonksiyonel ilişkisi ve arşivsel bağı ortaya çıkarılmaya çalışıır.

Arşivsel bağ: Belgelerin aynı fonksiyon kapsamında üretilen diğer belgeler, paydaşlar, kullanılan hukuki-idari işlem ve fonksiyon gibi dinamiklerle olan ilişkisini kurabilmek olarak tanımlanmıştır (Duranti, 1997, s. 213; InterPARES Project, 2002, s. 1). Diğer bir deyişle arşivsel bağ, üretildiği ve taşındığı ortam ne olursa olsun belgelerin 
üretilmesinden arşive intikal edene kadar geçirdiği yaşam evresinde kim tarafından, hangi idari işlem ve fonksiyon kapsamında üretildiğini, kime devredildiğini, nasıl dosyalandığını ve hangi seride bulundunu açıklayıp; bu seri içerisinde ait olduğu vaka yada konu dosyasıyla ve bu dosyada diğer belgelerle ilişkisini kurabilmektir. Başta karmaşık gibi gözüken bu ilişki ağında, belgenin üretildiğinde veya alınıp kullanıldığında kaynağına, iletilme ve kullanılması sırasında ortaya çıkan zorunluluklara ve her belgenin ortaya çıkışında bulunması gereken bileşenlere odaklanılır (InterPARES Project, 2000b, s. 50). Bu yapılırken belgeye verilen dosya kodu, kişiler, kayıt işlemleri ve üst veri elemanları gibi unsurlar kullanılır.

\section{Elektronik Belgelerin Arşivsel Bağı}

Elektronik ortamdaki belgelerin arşivsel bağının önemi, daha çok farklı format ve türlerde üretilen belgelerin bütünlüğünün sağlanması ihtiyacından kaynaklanmaktadır. Burada amaç, belgelerin üretilmesinden arşiv işlemlerine kadar olan süreçte bütünlüğü ve sürekliliği sağlayabilmektir. Bu yüzden arşivsel bağ, elektronik belge yönetiminde "belgeler arasındaki bilgisayar ağı" olarak da adlandırılmaktadır (Duranti ve Guercio, 1997).

Arşivsel bağın kurulmasında belgenin üretildiği ortamın etkili olduğu görülmektedir. Kağıt belgeler için önceden beri klasik yöntemler göz önünde bulundurulmakta, arşiv uygulamalarında bu bağ belge, dosya, seri ve fon bilgilerinden yararlanarak kurulabilmekteydi. Elektronik belgelerde ise bu bilgiler yeterli olmamaktadır. Önceden beri belgelerin arşivsel bağının kurulmasında provenans en geçerli metot iken, elektronik belgelerle beraber bu anlayış daha çok fonksiyonel ilişkiye dönüşmeye başlamıştır (McKemmish, Acland, Ward ve Reed, 1999). Belgelerin yaşam süreçlerindeki bu ilişki ağı, özellikle elektronik begelerle birlikte son dönemde "süreklilik modeli" (records continuum) gibi yeni arayışlar ortaya çıkarmıştır. Avusturya ve Yeni Zellanda'daki belge yönetimi kuramcılarının geliştirdiği bu modelde, belgelerin üretim işlemlerini de içerecek şekilde birbirinden kopuk olmayan bir işlem dizisi üzerinde yönetilmeleri benimsenmektedir (Odabaş, 2009, s. 196). Gerek fonksiyonel ilişki ağının kurulması, gerekse süreklilik modelinde, özellikle elektronik belgelerin yönetimi sürecinde yer alan adımlar arasındaki kopukluğu giderip, üretiminden arşiv uygulamalarına kadar tüm yaşam evresini takip edebilmek amaçlanmaktadır. Burada temel gerekçe, iletişim teknolojisinin sağladığı imkânlar kullanılarak, belgelerin hem kurum içerisinden, hem de dışarıdan asttan üste üstten asta yatay ve dikey olarak iletilmesi, bu bağlamda kolaylıkla üretilip kullanılabilmesini sağlayabilmektir (Ataman, 2008, s. 74). Aksi halde belgelerle üretildiği kaynak arasındaki ilişkinin kurulamaması söz konusu olabilir. Bu durum, belgelerin arşivsel bağının zarar görmesiyle sonuçlanır. Bu olumsuzluk, belgeleri güncel safhada yönetmeyi güçleştirdiği gibi arşivciyi de kaynağı ve mülkiyeti yeteri kadar açık olmayan bir malze ile yüz yüze bırakır. Dolayısıyla fonksiyonel ilişki anlayışında, belgeyle ilgili kesintisiz, sürekliliği olan, güvenilir bir emanet zincirinin kurulabilmesi ve bunun belgelenmesi düşüncesi yatmaktadır. 
Geleneksel belgelerde arşivsel bağ, belgenin dokümanter formunda örtük olarak bulunmakta, onun fiziksel düzenlemesi yapılırken belirlenmekteydi. Elektronik belgelerde ise bu bağın, belgenin arşiv işlemlerini beklemeden onun özgünlüğünün ve güvenilirliğinin temini için başta açığa çıkarılması gerektiği anlaşılmaktadır. Başka bir deyişle, belge arşiv malzemesi olduğunda değil, güncel safhadaki belge yönetimi uygulamalarında, hatta bürolardaki kullanımı sırasında bu ilişki ağı kurulabilmelidir. Aksi halde fonksiyonel ilişkileri kurulmamış belge kümeleri, bütünlüğü sağlanmaksızın tutulmaya çalışıldığında, sayısal ortamdaki depolarda yığınlar oluşturmaktan başka bir işe yaramayacaktır. Çünkü bunlar aynı zamanda güvenilirliği tam olmayan ve güvenliği temin edilmemiş belgeleri oluşturacaktır. Bu sebeple elektronik belgelerin üretilmeleri ve kullanılma koşulları göz önüne alındığında, yönetimleriyle alakalı hangi yöntem benimsenirse benimsensin bu bağın kurulmasında titiz davranılması gerektiği açıktır.

Arşiv bilimi belgelerin her birini bir varlık olarak kabul edip değerlendirirken; aynı zamanda onları belge hiyerarşisi olarak da ifade edilen fon, alt fon, seri, dosya ve belge düzeylerinde ele alarak daha çok organik ilişki içerisinde bir bütün olarak görür (Kandur, 2006, ss. 22-23) Bu hiyerarşik ilişki ağı, taşıyıcı otamı ne olursa olsun bütün belgeler için kurulabilmelidir. Ancak, elektronik belgelerin özel koşulları sebebiyle bu ilişki ağını kurmak oldukça güç gözükmektedir. Elektronik belge yönetimiyle ilgili çıkarılan TS 13298 standartı gibi bir takım prosürlerle bu olumsuzluk aşılmaya çalışılsa da gerek standartta öngörülen sistem kriterlerinin tam yerine getirilememesi, gerekse bu kriterleri belge yönetimi metodolojisini göre geliştirip uygulayacak yeterlilikte bilgi ve belge uzmanının eksikliği gibi çeşitli sebeplerden dolayı teorinin gerçek uygulamalara yansıtılmasında güçlükler yaşandığı bilinmektedir. Oysa elektronik belgelerin üretilmesi, kullanılması ve sahipliği noktasında kontekste dayalı arşivsel bağın, hem belge yönetimi uygulamalarında hem de arşiv işlemlerinde kurulması gerekir. Arşivcilerin ve belge uzmanlarının bunu yapabilmeleri için belgelerin üretilme ortamları, kontrol edilme ve iletilme şekilleri, fonksiyonel ilişkileri ve dokümanter yapıları üzerine çalışmaları gerekmektedir (Duranti, 1997, s. 213).

Elektronik belgeler, ait oldukları fonksiyonun farklı adımları sırasında ortaya çıkan diğer belgelerle ilişki içindedir. Bu ilişki, fonksiyonun idari işlemleri sebebiyledir. Aynı fonksiyon kapsamında olmasına rağmen her işlem adımında farklı bir belge sürece katılır. Farklı nitelikte ve formattaki bu belgeler, şüphesiz aynı fonksiyonla ilişkilidir. Belgelerin sahip oldukları bir takım form özellikleri, kapalı da olsa bu ilişkiyi açığa çıkaracak veriler sunar. İşte arşivsel bağın kurulmasına yarayacak olan açığı çıkarılmamış bu ilişki, belge üzerinde diplomatik niteleme yapılarak belirlenen farklı enstrümanlar aracılığı ile kurulmaya çalışılır. Belgenin ait olduğu fonksiyonu, aynı zamanda bulunması gereken vaka ya da konu dosyasını gösteren bir sınıflandırma numarası, bu ilişkinin kurulmasında önemli bir araçtır. Örneğin "320" dosya kodu "ihale işlemleri" fonksiyonu için kullanılsın. 2009 yılında yapılan bir akaryakıt ihalesi ise idari işlemlerden dolayı Türkiye'deki kamu kurumlarının ihale işlemlerini denetleyip onay veren Kamu İhale Kurumundan "2009/36" ihale numarasını almış olsun. Burada konu numarası ve ihale numarası "320[2009/36]" biçiminde birleştirilerek, akaryakıt ihalesi işlemine ait dosyanın 
numarası olacaktır. Bu akaryakıt ihalesi kapsamında farklı tür, nitelik ve formattaki bütün belgeler belirtilen numarayı alarak işlem görecektir. Böylece 2009/35 ihale numaralı akaryakıt ihalesiyle alakalı gelen ve giden belgeler ile aynı ihaleyle ilişkili farklı yapıdaki materyaller belirtilen sınıflandırma numarası altında toplanarak dosyalanır. Böyle bir uygulama, elektronik belgenin arşivsel bağının kurulmasında önemli bir aşamadır. Bu yüzden geleneksel belgelerin düzenlenmesinde kullanılan dosya planları, elektronik belgeler için de vazgeçilmez olarak görülmüş, elektronik belge yönetimi standardındaki yerini almıştır (TSE, 2009, ss. 2-3).

Elektronik belge yönetimi standardı gibi prosedürlere göre düzenlenen bir sitemde arşivsel bağı kurmak daha kolayken, özellikle önceden yapılandırılmamış elektronik bilgi ve belge yönetimi uygulamalarında bu işlem pek mümkün gözükmemektedir. Faaliyetleri önceden planlanmamış çalışmalarda arşivcileri daha zor görevler beklemektedir. Çünkü belgeye erişim için kullanılacak karmaşık üstveri elemanları dosya özellikleri içerisinde yeteri kadar açık olmayabilir. Eğer sistem karmaşık ise bu özellikler özel bir gayretle belirgin hale getirilebilir (Esteva, Xu, Sreevelsan-Nair, Athalye ve Hade, 2009 , s. 2). Örneğin belge yönetimi uygulamalarında, arşivsel bağın göstergesi olan evrak kayıt numarası, dosya numarası, indeks terimleri, zaman damgası, elektronik imza, dosya ismi, şifreleme özellikleri vb. elemanlar, standart yapıda kolaylıkla bulunabilirken, karmaşık sistemlerde bunların tespiti oldukça zordur (Duranti ve MacNeil, 1996, s. 53). Bunları ortaya çıkarabilmek için belge uzmanlarının fazladan zaman ayırmaları gerekmektedir.

\section{Sonuç}

Diplomatik metodun temelleri, her ne kadar XVII. yüzyılda atılmış olsa da koyduğu kurallar bugün elektronik belgelerin incelenmesi için de kullanılabilmektedir. Geleneksel diplomatik anlayışla çağdaş arşivsel diplomatik arasında dönem ve belge özelliklerinden kaynaklanan çeşitlifarklılıklar bulunmasına rağmen, belge uzmanlarıbelgeleri kritiketme yöntemi olan diplomatik metodu elektronik belgelerin incelenmesine yönelik olarak teknolojik kontekst gibi yeni alanlar açarak kullanmaktadırlar. Böylece üretildikleri ve kullanıldıkları ortam itibariyle oldukça karmaşık gibi gözüken bir yapıya sahip elektronik belgelerin özgünlüğü, diplomatik analiz yöntemi ile değerlendirilebilmektedir.

Bu metodun kullanılmasında özellikle iki noktanın ön plana çıktığı görülmüştür. Bunlardan biri belgelerin orijinalliklerinin muhafazası için ilk üretildikleri gibi korunmaları; diğeri ise kullanılmaları, iletilmeleri ve muhafazaları dönemlerinde üretildiği kaynak ve diğer materyallerle bütünlüğü sağlanmış olarak kesintisiz bir emanet zincirinin kurulması düşüncesidir. Bu zincirin kurulması ise diplomatik yöntem kullanılarak belgelerin arşivsel bağının ortaya çıkarılmasıyla mümkündür. Özellikle elektronik belgelerin güvenilirliği ve bütünlüğü açısından bu bağın kurulmasının önemli olduğu anlaşılmıştır. Elektronik belgelerin bütünlüğünün temininde arşivsel bağ fonksiyonel ilişki anlayışıyla kurulmaktadır. Bu ilişki, hem belge üretilirken hem de 
iletilip muhafaza edilirken sahip olduğu form özellikleri incelenerek ortaya çıkarılabilir. Elektronik imzadan zaman damgasına, dosya kodundan üstveri elemanlarına kadar çok çeşitli bu özellikler, arşivsel bağın kurulmasına yardımcı olur. Öyle anlaşılıyor ki arşivciler provenans adlı belge düzenleme metodunun yanı sıra fonksiyonel ilişki ve belgelerde süreklilik modeli gibi yeni yaklaşımları da uygulayacaklardır. Özellikle elektronik belgelerin kontrolü için bu ve benzeri yeni eğilimler zorunluluk haline gelmektedir.

Gerek arşivsel bağın kurulması gerekse elektronik belgelerde özgünlüğün korunması meselesi tek bir meslek grubunun işi olarak görülmemelidir. Örgütlerde elektronik belge yönetimi modelleri geliştirilirken, bir programcı, sistem mühendisi ve kurum çalışanları yanı sıra mutlaka bilgi-belge uzmanı da görev almalıdır. Oluşturulacak ekipte, bilgi-belge uzmanı takımın bir üyesi olarak çalışacak, elektronik belgelerin arşivsel bağlarının kulmasında ve fonksiyonel ilişki ağının temininde yazılımcılara rehberlik edip, yol göstereceklerdir.

Bu sebeple elektronik belgelerin arşivsel bağının kurulmasında belge uzmanlarının yazılım ve donanım ile ilgili bir takım teknik bilgiye sahip olması gerektiği açıktır. Belgenin üretildiği ve kullanıldığı yazılıma ait çeşitli teknik özelliklerin yer aldığı teknolojik konteksti bilmeden onun ilişki ağını çözümleyebilmek pek mümkün gözükmemektedir. Burada arşivcilerden beklenen, bir yazılım mühendisinin bilgisine sahip olmak değil, elindeki malzemeyi yönetecek kadar konuyu bilmektir.

\section{Kaynakça}

American National Standards Institute-Association for Information Management Professionals (2007). The Digital records conversion process: Program planning, requirements, prosedures. 10 Nisan 2011 tarihinde http://www.arma.org/standards/DigitalConversion.cfm adresinden erişildi.

Artuk, M. E., Gökcen, A. ve Yenidünya, A. C. (2006). 5237 Sayılı kanuna göre ceza hukuku özel hükümler ( 7. bs). Ankara: Turhan Kitapevi.

Ataman, B. K. (2008). Enformasyon bilimlerine fütüristik yaklaşım. Bilgi Dünyası, 9(1), 67-89.

Bartlett, N. (1996). Diplomatics for photographic images: academic exoticism?. American Archivist, 59/4 (Fall), 486-494.

Beder, F. (2005). Elektronik belge yönetimi sistemi ve Türkiye Cumhuriyeti Merkez Bankası örneği. Uzmanlık yeterlilik Tezi, Türkiye Cumhuriyeti Merkez Bankası İletişim Genel Müdürlüğü, Ankara. 22 Mart 2010 tariihinde http://www.tcmb.gov.tr/kutuphane/TURKCE/tezler/ adresinden erişildi.

Bilgi Teknolojileri ve lletişim Kurumu. (2010). 5 Ocak 2010 tarihinde http://www.tk.gov.tr/ adresinden erişildi.

Çiçek, N. (2009). Modern belgelerin diplomatiği. İstanbul: Derlem.

Delmas B. (1996). Manifesto for a contemporary diplomatics: From institutional documents to organic information. American Archivist, 59/4 (Fall), 438-452.

Duranti, L. (1997). The Archival bond. Archives and Museum Informatics, 11, 213-218. 
Duranti, L. (1998). Diplomatics: new uses for an old science. Lanham: Society of American Archivists.

Duranti, L. (2009). From digital diplomatics to digital records forensic. Archivaria, 68 (Fall), 39-66.

Duranti, L. ve Guercio, M. (1997). Research issues in archival bond. Electronic Records Meeting'de sunulan bildiri. 23 Aralık 2009 tarihinde http://www.archimuse.com/erecs97/s1-ld-mg.HTM adresinden erişildi.

Duranti, L. ve MacNeil, H. (1996). The Protection of the integrity of electronic records: An overview of the UBC-MAS research project. Archivaria, 42(Fall), 46-67.

Electronic records management handbook. (2007). 26 Ağustos 2009 tarihinde http://www.osp.dgs. ca.gov/recs/erm-toc.htm adresinden erişildi.

Elektronik belge yönetimi. (2009). Türkiye Bilişim Derneği Web sitesinden 10 Nisan 2011 tarihinde erişildi: http://eski.tbd.org.tr/resimler/ekler/6e19e830859f2cb_ ek.pdf?tipi=27\&turu=X\&sube $=0$

Elektronik Imza Kanunu. (2004, 23 Ocak). T. C. Resmi Gazete, (25355). 5 Ocak 2009 tarihinde http:// www.tk.gov.tr/eimza/eimza_yasasi.htm adresinden erişildi.

Esteva, M., Xu, W., Sreevelsan-Nair, J., Athalye, A. ve Hade, M. (2009). Finding narratives of activities through archival bond in electronically stored information (ESI). DESI III Global E-Discovery/EDisclosure Workshop: A Pre-Conference Workshop at the $12^{\text {th }}$ International Conference on Artificial Intelligence and Law'da sunulan bildiri. 13 Ocak 2010 tarihinde http://www.law.pitt. edu/DESI3_Workshop/Papers/DESI_III.Esteva-Xu-Nair.pdf adresinden erişildi.

The International Research on Permanent Authentic Records in Electronic Systems Project. (1999). The International research on permanent authentic records in electronic systems. 15 Ocak 2010 tarihinde http://www.interpares.org/ip_director_welcome.cfm adresinden erişildi.

The International Research on Permanent Authentic Records in Electronic Systems Project. (2000a). Authenticity task force: Lineage of elements included in the template for analysis (pre-InterPARES): from traditional diplomatics to contemporary archival diplomatics. 23 Kasım 2007 tarihinde http://www.interpares.org/documents/interpares_ResearchMethodologyStatement.pdf adresinden erişildi.

The International Research on Permanent Authentic Records in Electronic Systems Project. (2000b). Authenticity task force: Research methodology statement. 23 Kasım 2007 tarihinde http://www.interpares.org/documents/interpares_ResearchMethodologyStatement.pdf adresinden erişildi.

The International Research on Permanent Authentic Records in Electronic Systems Project. (2000c). Authenticity task force: Appendix 2: Template for analysis. 2 Ocak 2010 tarihinde http:// www.interpares.org/display_file.cfm?doc=ip1_template_for_analysis.pdf adresinden erişildi.

The International Research on Permanent Authentic Records in Electronic Systems Project. (2002). Glossary: A controlled vocabulary of terms used in the InterPARES Project. 12 Ocak 2010 tarihinde http:// www.interpares.org/documents/InterPARES\%20Glossary\%202002-1.pdf adresinden erişildi.

Kandur, H. (2006). Elektronik belge yönetimi referans modeli (V.2.0). Ankara: Devlet Arşivleri Genel Müdürlüğü.

Kamusm.gov.tr. (2011). 9 Nisan 2011 tarihinde http://www.kamusm. gov.tr/ adresinden erişilmiştir. 
Kunde, N. (2009). Getting it done - collaboration and development of the digital records conversion standart. American Archivist, 72 (Spring-Summer), 146-159.

Külcü, Ö. ve Çakmak, T. (2009). Elektronik belge yönetimi üzerine InterPARES projesi ve Türkiye takımı faaliyetleri. Bilgi Dünyası, 10(2), 287-302.

McKemmish, S., Acland, G., Ward, N. ve Reed, B. (1999). Describing records in context in the continuum: the Australian recordkeeping metadata schema. Archivaria, 48 (Fall), 3-37. 12 Aralık 2009 tarihinde http://journals.sfu.ca/archivar/index.php/archivaria/article/ view/12715/13890 adresinden erişildi.

MacNeil, H. (2000). Trusting records: Legal, historical, and diplomatic perspectives. Dordrecht: Kluwer.

Maliye Bakanlığı. (2006, 11 Temmuz). Vergi Usul Kanunu Genel Tebliğ Sıra no: 361. T.C. Resmi Gazete, http://www.alomaliye.com/verusullar.htm adresinden erişilmiştir.

Model Requirements for the Management of Electronic Records. (2008). MoReq specification. 15 Nisan 2010 tarihinde http://www.cornwell. co.uk/moreqdocs/moreq.pdf adresinden erişildi.

Odabaş, H. (2009). E-devlet sürecinde elektronik belge yönetimi. İstanbul: Türk Kütüphaneciler Derneği İstanbul Şubesi.

Öberg, L. M.ve Borglund, E. (2006). What are the characteristics of records? International Journal of Public Information Systems, 1, 55-76. 23 Ocak 2010 tarihinde http://www.ijpis.net/issues/ no1_2006/IJPIS_no1_2006_p4.pdf adresinden erişildi.

Storch, S. E. (1998). Diplomatics: Modern archival method or medieval artifac. American Archivist, 61 (Fall), 365-378.

Tarık, T. (2008). Adres kayıt sistemi ile kent bilgi sisteminin bütünleştirilmesi.Jeodezi, Jeoinformasyon ve Arazi Yönetimi Dergisi, 99, 13-22. 7 Ocak 2009 tarihinde http://www.hkmo.org.tr/resimler/ ekler/65e8a 413d0562de_ek.pdf adresinden erişildi.

Türk Standartları Enstitüsü. (2007). Bilgi ve dokümantasyon-elektronik belge yönetimi. Ankara: Yazar. (TS 13298: 2007).

Türk Standartları Enstitüsü (TSE). (2009). Elektronik belge yönetimi. Ankara: Yazar. (TS 13298: 2009).

Telekomünikasyon Kurumu. (2005, 6 Ocak). Elektronik İmza Kanununun Uygulanmasına İlişkin Usul ve Esaslar Hakkında (25692). 5 Ocak 2009 tarihinde http://www.mevzuat.adalet.gov.tr/ html/23061.html adresinden erişildi.

Vergi Usul Kanunu. (1961, 4 Ocak). T.C. Resmi Gazete, ( 10703-10705). 11 Ağustos 2008 tarihinde http://www.mevzuat.adalet.gov.tr/html/1045.html adresinden erişildi.

Williams, C. (2005). Diplomatic attitudes: From Mabillon to metadata. Journal of the Society of Archives, 26(1), 1-24. 